\title{
Synthesis and Characterization of Substituted Phenyl Azetidines as Potential Antimicrobial Agents
}

\author{
K. DORASWAMY and P. VENKATA RAMANA* \\ Department of Chemistry, Sri Krishnadevaraya University, Anantapur- 515 003, India \\ ramanapv54@gmail.com
}

Received 10 September 2012 / Accepted 20 October 2012

\begin{abstract}
The reaction of 2-(4-bromo phenyl) methyl cyanide (1a) with ethylchloroformate in the presence of $n$-butyl lithium gave ethyl-2-(4-bromo phenyl)-2-cyano acetate (2a). 2a on reduction with sodium borohydride yields 3-amino-2-(4-bromo phenyl) propan-1-ol (3a). Compound 3a on further reaction with tert butyloxy anhydride in presence of triethylamine afford tert-butyl-2-(4-bromo phenyl)-3hydroxy propyl carbamate (4a). 4a on treatment with tosyl chloride gave 2-(4-bromo phenyl)-3(tertiarybutyloxy carbonyl amino)-propan-1-ol-(4-toluene sulphonate) (5a). Compound 5a on cyclization followed by hydrolysis gave 3-(4-bromo phenyl) azetidine (7a). Compounds $\mathbf{2 b - 2 e , 3 b - 3 e , ~}$ 4b-4e, 5b-5e, 6b-6e and $7 b-e$ were synthesized by a similar method. The compounds are characterized by elemental analysis, IR, ${ }^{1} \mathrm{H}$ NMR and Mass spectral analysis and screened for antimicrobial activity.
\end{abstract}

Keywords: Substituted azetidines, Borane reduction, Antimicrobial activity

\section{Introduction}

The chemistry of heterocyclic compounds is an interesting area in medicinal chemistry as it offers challenging tasks in development of novel synthetic strategies ${ }^{1}$. Azetidines are fascinating synthetic targets because of their remarkable chemical and biological properties ${ }^{2-11}$. The azetidine ring system prominently features in many medicinally important molecules some of which are markedly active against influenza A H2N2 virus ${ }^{12}$ and have anti-HIV-1, anti-HSV-1 and HSV-2 potential ${ }^{13}$. Although the inherent strain associated with the azetidine ring leads to difficulties in its construction, functionalization and modifications, it is advantageous for its synthetic applications involving ring-opening reactions. For example, several functionalized azetidines have been used as masked 1,4-dipoles for the synthesis of five and six membered aza-heterocycles ${ }^{14-17}$. 3-Substituted azetidines are the most important constituent of various potential therapeutic moieties ${ }^{9-11}$. Among various methods available for synthesis of tri substituted azetidines, the most general involves the cyclisation of $\gamma$ - amino alcohols or their derivatives ${ }^{18-22}$. The development of drug resistance to existing anti-microbial treatment has lent to research for novel more effective antimicrobial and antifungel agents. In view of these data, we aimed the synthesis of new substituted phenyl azetidines as novel antimicrobial agents. Purity of all the synthesized compounds was checked by TLC and characterized by elemental analysis, IR, ${ }^{1} \mathrm{H}$ NMR and Mass. 


\section{Experimental}

All the chemicals were purchased from Merck, Qualigens, Sd Fine \& Loba Chemi. The reagents and solvents were of analytical grade and as when needed purified by the standard procedures. Purity of the compounds was checked by TLC on silica gel G plates. The spots were located by keeping the plates under the UV light, in a solutions of ninhydrin and $\mathrm{KMnO}_{4}$. All the melting points were taken in open capillaries on electro thermal apparatus and are uncorrected. IR spectra were recorded as $\mathrm{KBr}$ on a Perkin Elmer - FTIR specrum100. ${ }^{1} \mathrm{H}-\mathrm{NMR}$ spectra were recorded on Bruker spectrophotometer $(400 \mathrm{MHz})$ using $\mathrm{CDCl}_{3}$ as solvent and TMS as internal standard. Chemical shifts were reported in $\delta \mathrm{ppm}$ units. Elemental analysis was performed on a Heracus $\mathrm{CHN}$ analyzer. Analysis indicated by the symbols of the elements of functions were within $\pm 0.4 \%$ of the theoretical values.

\section{General procedure for the synthesis}

\section{Synthesis of ehyl-2-(4-bromo phenyl) 2- cyano acetate (2a-e)}

2-(4-Bromo phenyl) methyl cyanide (1a) / 2-substituted methyl cyanide was dissolved in tetrahydrofuran and then cooled to $-78{ }^{\circ} \mathrm{C}, n$-butyl lithium was then slowly added and kept at the same temperature for half an hour. Ethylchloroformate was then added. After the completion of addition the temperature was maintained at $-78{ }^{\circ} \mathrm{C}$ for two hours. Progress of the reaction was monitored by TLC plates by using ethyl acetate and petroleum ether (3:7) as an elutent and observed under UV light. After completion of the reaction, the resulting mixer was quenched with dil. hydrochloric acid and then extracted with ethyl acetate twice. Ethyl acetate layer was collected, dried over anhydrous sodium sulphate and evaporated to get ehyl-2-(4-bromo phenyl) 2- cyano acetate (2a). Yield: $82 \%$, m. p. $125{ }^{\circ} \mathrm{C}$. Compounds 2b-e were prepared similarly. The melting points of the compounds $2 \mathbf{b}-\mathbf{e}$ are $106{ }^{\circ} \mathrm{C}, 183{ }^{\circ} \mathrm{C}$, $113{ }^{\circ} \mathrm{C}$ and $141{ }^{\circ} \mathrm{C}$ respectively.

FTIR (KBr) cm$^{-1}$ : 3060 (C-H stretch in phenyl ring), 2920 (aliphatic C-H stretch), 2252(CN stretch nitrile), $1746(\mathrm{C}=\mathrm{O}$ stretch in ester), $1180(\mathrm{C}-\mathrm{O}-\mathrm{C}$ stretch $), 1590(\mathrm{C}=\mathrm{C}$ stretch in aromatic ring).

${ }^{1} \mathbf{H}$ NMR $\left(\mathbf{C D C l}_{\mathbf{3}}\right) \boldsymbol{\delta} \mathbf{p p m}: 1.33\left(\mathrm{t}, 3 \mathrm{H},-\mathrm{CH}_{2}-\mathrm{CH}_{3}\right) ; \delta 4.22\left(\mathrm{q}, 2 \mathrm{H},-\underline{\mathrm{CH}}_{2}-\mathrm{CH}_{3}\right) ; \delta 4.52(\mathrm{~s}$, $1 \mathrm{H}$, methine); $\delta 6.87\left(\mathrm{~d}, 2 \mathrm{H}, \mathrm{C}_{2} \& \mathrm{C}_{6} \mathrm{Ar}-\mathrm{H}\right) ; \delta 7.24$ (d, 2H, $\left.\mathrm{C}_{3} \& \mathrm{C}_{5} \mathrm{Ar}-\mathrm{H}\right)$.

\section{Synthesis of 3-amino-2-(4-bromo phenyl) propan-1-ol (3a-e)}

Sodiumborohydride was dissolved in the tetrahydrofuran and then borontrifluoroetherate was added slowly and cooled to $-10{ }^{\circ} \mathrm{C}$ and kept at this temperature for $30 \mathrm{~min}$. Ethyl-2-(4bromo phenyl)-2-cyano acetate (2a) dissolved in small amount of THF was then added and kept at $-10{ }^{0} \mathrm{C}$ for 4 hours. Reaction progress was monitored by TLC plates by using methanol and chloroform (1:9) as an eluent and observed under UV light and ninhydrin solution. The reaction mixer was quenched with dil. hydrochloric acid and the temperature raised to $50{ }^{\circ} \mathrm{C}$ in order to break the boron complex and then extracted with ethylacetate twice. The organic layer was collected and dried over anhydrous sodium sulphate and evaporated to get 3-amino-2-(4-bromo phenyl) propan-1-ol (3a). Yield: 76\%, m. p: $141{ }^{\circ} \mathrm{C}$. Compounds $\mathbf{3 b}$-e were prepared similarly and the melting points of the compounds $\mathbf{3 b}$-e are $119{ }^{\circ} \mathrm{C}, 198{ }^{\circ} \mathrm{C}, 126{ }^{\circ} \mathrm{C}$ and $158{ }^{\circ} \mathrm{C}$ respectively.

FTIR (KBr) cm ${ }^{-1}$ : 3625 (O-H stretch in alcohol), 3496 (N-H stretch in amine), 3060 (C-H stretch in phenyl ring), 2920 (C-H stretch in aliphatic compounds), 1630 (N-H bend in amine), 1595 ( $\mathrm{C}=\mathrm{C}$ stretch in aromatic ring). 
${ }^{1} \mathbf{H}$ NMR $\left(\mathbf{C D C l}_{3}\right) \boldsymbol{\delta} \mathbf{~ p p m}: 1.89\left(\mathrm{~s}, 2 \mathrm{H},-\mathrm{NH}_{2}\right), 2.32(\mathrm{~s}, 1 \mathrm{H}, \mathrm{OH}), 2.82,3.7(\mathrm{~d}, 2 \mathrm{H},-$ $\underline{\mathrm{CH}}_{2}-\mathrm{NH}_{2}$ ), 3.94, 3.69 (d, $\left.2 \mathrm{H},-\underline{\mathrm{CH}}_{2}-\mathrm{OH}\right), 3.15$ (m, $1 \mathrm{H}$, methine proton), 7.05 (d, $2 \mathrm{H}, \mathrm{C}_{2}$ \& $\mathrm{C}_{6}$ of $\left.\mathrm{Ar}-\mathrm{H}\right), 7.26$ (d, 2H, $\mathrm{C}_{3} \& \mathrm{C}_{5}$ of $\left.\mathrm{Ar}-\mathrm{H}\right)$.

\section{Synthesis of Tert-butyl-2-(4-bromo phenyl)-3-hydroxypropylcarbamate (4a-e)}

3-Amino-2-(4-bromo phenyl) propan-1-ol was dissolved in chloroform and cooled to $0{ }^{\circ} \mathrm{C}$. Then tri ethyl amine and BOC anhydride were slowly added. The resulting solution was stirred for two hour at room temperature. Reaction progress was monitored by TLC plates by using ethyl acetate and petroleum ether (3:7) as an elutent and observed under UV light and ninhydrin solution. The reaction mixer was washed several times with $0.1 \mathrm{M}$ hydrochloric acid. Organic layer was separated, washed with chloroform, dried over anhydrous sodium sulphate and evaporated to get tert-butyl-2-(4-bromo phenyl)-3hydroxypropylcarbamate (4a). Yield: $63 \%$, m. p: $208{ }^{\circ} \mathrm{C}$. Remaining members of series $4 \mathbf{b}$-e were similarly prepared and melting points of the compounds $4 \mathbf{b}-\mathbf{e}$ are $190{ }^{\circ} \mathrm{C}, 268{ }^{\circ} \mathrm{C}$, $200{ }^{\circ} \mathrm{C}$ and $223{ }^{\circ} \mathrm{C}$ respectively.

FTIR (KBr) cm$^{-1}$ : 3630 (O-H stretch in alcohol), 3420 (N-H stretch in carbamate), 3065 (C-H stretch in phenyl ring), 2925 (C-H stretch of methyl), 1764 (C=O stretch in carbamates), $1605(\mathrm{C}=\mathrm{C}$ stretch in aromatic ring).

${ }^{1} \mathbf{H}$ NMR $\left(\mathbf{C D C l}_{3}\right) \boldsymbol{\delta} \mathbf{~ p p m}: 1.43$ (s, 9H, tert butyl), 2.30 (s, 1H, -O-H), 3.13, 3.38, (d, $\left.-\underline{\mathrm{CH}}_{2}-\mathrm{NH}_{2}\right), 3.69,3.94\left(\mathrm{~d}, 2 \mathrm{H},-\underline{\mathrm{CH}}_{2}-\mathrm{OH}\right), 3.75$ (m, $1 \mathrm{H}$, methine proton), $7.05\left(\mathrm{~d}, 2 \mathrm{H}, \mathrm{C}_{2}\right.$ $\& \mathrm{C}_{6}$ of $\left.\mathrm{Ar}-\mathrm{H}\right), 7.28$ (d, 2H, $\mathrm{C}_{3} \& \mathrm{C}_{5}$ of $\left.\mathrm{Ar}-\mathrm{H}\right) ; 8.62$ (s, $1 \mathrm{H},-\mathrm{NH}$ - carbamate).

Synthesis of 2-(4-bromo phenyl)-3-(tertiarybutyloxycarbonyl amino)-propan-1-ol(4-toluene sulphonate) (5a-e)

Tert-butyl-2-(4-bromo phenyl)-3-hydroxy propyl carbomate was dissolved in the absolute alcohol and then $2 \mathrm{Eq}$. of sodium hydroxide and tosyl chloride were added in portions. The reaction mixture was heated under reflux for $10 \mathrm{~h}$. at $80{ }^{\circ} \mathrm{C}$. The reaction was monitored by TLC plates by using ethyl acetate and petroleum ether (5:5) as an elutent and observed under UV light and $\mathrm{KMnO}_{4}$ solution. After completion of the reaction, solvent was distilled off completely and then water was added to the crude residue and extracted twice with dichlromethane. The organic layer was collected, dried over anhydrous sodium sulphate and solvent is evaporated to get 2-(4-bromo phenyl)-3-(tertiarybutyloxy carbonyl amino)propan-1-ol-(4-toluene sulphonate). Yield: 80\%, m.p: $289{ }^{0} \mathrm{C}$. Compounds 5b-e were similarly prepared and the melting points of the compounds $\mathbf{5 b}$-e are $267{ }^{\circ} \mathrm{C}, 345{ }^{\circ} \mathrm{C}, 277^{\circ} \mathrm{C}$ and $303{ }^{\circ} \mathrm{C}$ respectively.

FTIR (KBr) cm$^{-1}$ : 3420 (N-H stretch in carbamate), 3060 (C-H stretch in aromatic ring), 2960 (C-H stretch of methyl in tert butyl), $2935\left(\mathrm{C}-\mathrm{H}\right.$ stretch in $\left.\mathrm{CH}_{2}-\mathrm{NH}\right), 1764(\mathrm{C}=\mathrm{O}$ stretch in carbamates), $1605(\mathrm{C}=\mathrm{C}$ stretch in aromatic ring $), 1215\left(\mathrm{SO}_{3}\right.$ asym stretch in tosylate), $1032\left(\mathrm{SO}_{3}\right.$ sym stretch in tosylate), $690\left(\mathrm{~S}-\mathrm{O}\right.$ stretch in $\left.\mathrm{SO}_{3}\right)$.

${ }^{1} \mathbf{H}$ NMR $\left(\mathbf{C D C l}_{3}\right) \boldsymbol{\delta} \mathbf{~ p p m}: 1.44$ (s, 9H, tert butyl), 2.38 (s, 3H, methyl), 3.13, 3.38 (d, 2H, $\left.-\mathrm{CH}_{2}-\mathrm{NH}-\mathrm{BOC}\right), 3.69,3.94\left(\mathrm{~d}, 2 \mathrm{H},-\mathrm{CH}_{2}-\mathrm{O}-\right.$ tosyl), 3.74 (m, 1H, methine proton), $7.05\left(\mathrm{~d}, 2 \mathrm{H}, \mathrm{C}_{2} \& \mathrm{C}_{6}\right.$ of $\left.\mathrm{Ar}-\mathrm{H}\right), 7.28\left(\mathrm{~d}, 2 \mathrm{H}, \mathrm{C}_{3} \& \mathrm{C}_{5}\right.$ of $\left.\mathrm{Ar}-\mathrm{H}\right), 7.36\left(\mathrm{~d}, 2 \mathrm{H}, \mathrm{C}_{2} \& \mathrm{C}_{6}\right.$ of $\mathrm{H}_{3} \mathrm{C}-\mathrm{Ar}-\mathrm{H}$ ), 7.78 (d, 2H, $\mathrm{C}_{3} \& \mathrm{C}_{5}$ of $\left.\mathrm{H}_{3} \mathrm{C}-\mathrm{Ar}-\mathrm{H}\right), 8.62$ (s, 1H, NH carbomate).

\section{Synthesis of tert-butyl-3-(4-bromophenyl) azetidine-1-carboxylate (6a-e)}

Compound 5a was dissolved in the acetonitrile and then cesium carbonate was added. The reaction mixture was heated under reflux for six hours at $80{ }^{\circ} \mathrm{C}$. Progress of the reaction was 
monitored by TLC plates by using ethyl acetate and petroleum ether (5:5) as an elutent and observed under UV light and ninhydrin solution. After completion of reaction water was added to the reaction mixture and separated the acetonitrile layer. Then two water washings were given to acetonitrile layer, dried over anhydrous sodium sulphate and evaporated to get tert-butyl- 3-(4-bromophenyl) azetidine-1-carboxylate (6a). Yield: $85 \%$, m.p: $162{ }^{\circ} \mathrm{C}$. Other members of the series $\mathbf{6 b}-\mathbf{e}$ were similarly prepared and melting points of the compounds 6b-e are $139{ }^{\circ} \mathrm{C}, 220{ }^{\circ} \mathrm{C}, 152{ }^{\circ} \mathrm{C}$ and $175{ }^{\circ} \mathrm{C}$ respectively.

FTIR (KBr), $\mathbf{~ c m}^{-1}$ : 3062 (C-H stretch in aromatic ring), 2945 (C-H stretch in methyl), 2852 (C-H stretch in azetidine), 1715 ( $\mathrm{C}=\mathrm{O}$ stretch in ester), 1180 (C-O-C stretch in ester), $1615(\mathrm{C}=\mathrm{C}$ stretch in aromatic ring $)$.

${ }^{1} \mathbf{H}$ NMR ( $\mathbf{C D C l}_{3}$ ) $\boldsymbol{\delta}$ ppm: 1.45 (s, 9H, tert butyl), 3.75 (m, 1H, methine proton), 4.15, $4.32\left(\mathrm{~d}, 2 \mathrm{H}\right.$, methylene in azetidine ring), $7.05\left(\mathrm{~d}, 2 \mathrm{H}, \mathrm{C}_{2} \& \mathrm{C}_{6}\right.$ of $\left.\mathrm{Ar} \mathrm{C}-\mathrm{H}\right), \delta 7.30\left(\mathrm{~d}, 2 \mathrm{H}, \mathrm{C}_{3}\right.$ $\& \mathrm{C}_{5}$ of $\left.\mathrm{Ar}-\mathrm{H}\right)$.

\section{Synthesis of 3-(4- bromo phenyl) azetidine (7a-e)}

Tert-butyl-3-(4-bromo phenyl) azetidine-1-carboxylate was dissolved in methanolic hydrochloric acid and stirred for 2 hours. Methanol was then distilled off and sodium carbonate solution was added to the crude product and extracted with dichloromethane. The organic layer was dried over anhydrous sodium sulphate and then evaporated to get 3-(4bromo phenyl) azetidine (7a) Yield: 76\%. Compounds 7b-e were similarly prepared.

FTIR (KBr), $\mathbf{c m}^{-1}$ : 3460 (N-H stretch in azetidine), 3065 (C-H stretch in aromatic ring), $2850\left(\mathrm{CH}_{2}\right.$ stretch in azetidine $), 1610(\mathrm{C}=\mathrm{C}$ stretch in aromatic ring $)$.

${ }^{1} \mathbf{H}$ NMR $\boldsymbol{\delta}$, ppm: 2.55 (s, $1 \mathrm{H}, \mathrm{NH}$ in azetidine), $3.75(\mathrm{~m}, 1 \mathrm{H}$, methine proton in azetidine ring), 4.15, $4.30\left(\mathrm{~d}, 2 \mathrm{H}\right.$, methylene in azetidine ring), $7.05\left(\mathrm{~d}, 2 \mathrm{H}, \mathrm{C}_{2} \& \mathrm{C}_{6}\right.$ of $\left.\mathrm{Ar} \mathrm{C}-\mathrm{H}\right)$, $7.28\left(\mathrm{~d}, 2 \mathrm{H}, \mathrm{C}_{3} \& \mathrm{C}_{5}\right.$ of $\left.\mathrm{Ar} \mathrm{C}-\mathrm{H}\right)$.

\section{Antimicrobial activity}

The synthesized compounds 7a-e were screened for their in vitro antibacterial activity against Staphylococcus aureus, Esherichia coli, Pseudomonas aureus and Salmonella typhi and antifungal activity against Aspergillus niger, Candida albicans by measuring the zone of inhibition in $\mathrm{mm}$. The microbial activity was performed by cup plate method at concentration $500 \mu \mathrm{g} / \mathrm{mL}$ and reported in Table 2. Nutrient agar was employed as culture medium and DMSO was used as solvent control for antimicrobial activity. Penicillin and griseofulvin were used as standard for antibacterial and antifungal activities respectively.

\section{Results and Discussion}

In the present work a series of new compounds were synthesized. The reaction of 2-(4-bromo phenyl) methyl cyanide (1a) with ethylchloroformate and $n$-butyl lithium used as a base followed by reduction with borane yielded the ethyl 2-(4-bromo phenyl) -2-cyano acetate (2a) and 3-amino -2- (4-bromo phenyl) propan-1-ol (3a) respectively. The compound 3a on further reaction with tertiary butyloxy anhydride and tri ethyl amine followed by tosylchloride and sodium hydroxide gives $4 \mathbf{a}$ and 5a. The compound 5a then cyclization with cesium carbonate and methanolic hydrochloric acid gives 3-(4- bromo phenyl) azetidine (7a). The compounds $\mathbf{2 b - 7 b , 2 c - 7 c , ~ 2 d - 7 d ~ a n d ~ 2 e - 7 e ~ w e r e ~ s y n t h e s i z e d ~ i n ~ t h e ~ s a m e ~}$ method. The compounds 1a-7e are shown in Scheme 1. Physical constants, elemental analysis and mass of molecular ion peak of prepared compounds 7a-e are shown in Table 1. The structures of the various synthesized compounds were assigned on the basis of 
elemental analysis, IR and ${ }^{1} \mathrm{H}-\mathrm{NMR}$ spectral data. The compounds are evaluated for their antimicrobial activity and results are summarized in Table 2. From the antimicrobial screening it was observed that all the compounds exhibited activity against all the organisms employed. Looking from the structure activity relationship angle, marked inhibition in

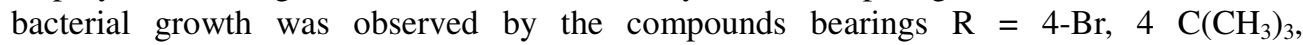
3, 4 -dichloro (7a, 7d, 7e) substituents whereas compounds $\mathrm{R}=4-\mathrm{OCF}_{3}, 4-\mathrm{OC}_{6} \mathrm{H}_{5}(\mathbf{7 b}, \mathbf{7 c})$ showed moderate to good activity. Fungicidal screening data also revealed that compounds bearing $\mathrm{R}=4-\mathrm{Br}, 4 \mathrm{C}\left(\mathrm{CH}_{3}\right)_{3}, 3$, 4 Dichloro (7a, 7d, 7e) imparted maximum activity to the compounds, whereas compounds $\mathrm{R}=4-\mathrm{OCF}_{3}, 4-\mathrm{OC}_{6} \mathrm{H}_{5}(\mathbf{7 b}, \mathbf{7} \mathbf{c})$ showed moderate to good activity.

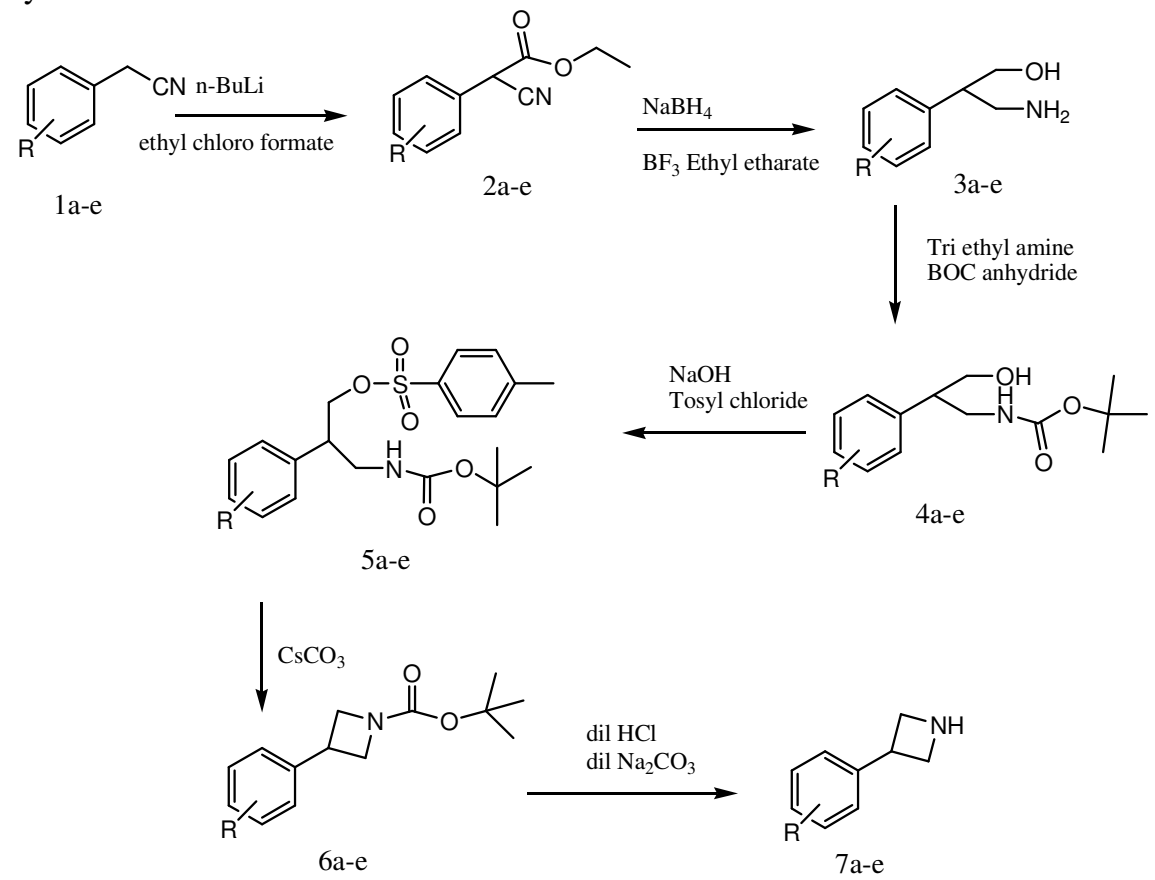

Scheme 1. R=(a) $4 \mathrm{Br}$, (b) 4-O-CF 3 , (c) 4-O- $\mathrm{C}_{6} \mathrm{H}_{5}$, (d) 4-C $\left(\mathrm{CH}_{3}\right)_{3}$ \& (e) 3,4-Di chloro

Table 1. Physical constants, mass of molecular ion peak and elemental analysis of titled compounds 7a-e

\begin{tabular}{|c|c|c|c|c|c|c|c|}
\hline \multirow{2}{*}{ Compd } & \multirow{2}{*}{$\mathrm{R}$} & \multirow{2}{*}{$\begin{array}{c}\text { Mol. } \\
\text { Formula }\end{array}$} & \multirow{2}{*}{$\mathrm{m} \cdot \mathrm{p}^{0} \mathrm{C}$} & \multirow{2}{*}{$\begin{array}{c}\text { mass } \\
m / z, \mathbf{M}^{+}\end{array}$} & \multicolumn{3}{|c|}{ Elemental analysis, $\%$} \\
\hline & & & & & $\mathrm{C}$ & $\mathrm{H}$ & $\mathrm{N}$ \\
\hline $7 \mathbf{a}$ & $4-\mathrm{Br}$ & $\mathrm{C}_{9} \mathrm{H}_{10} \mathrm{BrN}$ & 132 & 212 & $\begin{array}{c}50.97 \\
(50.93)\end{array}$ & $\begin{array}{c}4.75 \\
(4.75)\end{array}$ & $\begin{array}{c}6.60 \\
(6.58)\end{array}$ \\
\hline $7 b$ & $4-\mathrm{O}-\mathrm{CF}_{3}$ & $\mathrm{C}_{10} \mathrm{H}_{10} \mathrm{~F}_{3} \mathrm{NO}$ & 110 & 217 & $\begin{array}{c}55.30 \\
(55.29)\end{array}$ & $\begin{array}{c}4.64 \\
(4.60)\end{array}$ & $\begin{array}{c}6.45 \\
(6.45)\end{array}$ \\
\hline 7c & $4-\mathrm{O}-\mathrm{C}_{6} \mathrm{H}_{5}$ & $\mathrm{C}_{15} \mathrm{H}_{15} \mathrm{NO}$ & 187 & 225 & $\begin{array}{c}79.97 \\
(79.89)\end{array}$ & $\begin{array}{c}6.71 \\
(6.65)\end{array}$ & $\begin{array}{c}6.22 \\
(6.21)\end{array}$ \\
\hline 7d & $\begin{array}{c}4-\mathrm{C} \\
\left(\mathrm{CH}_{3}\right)_{3}\end{array}$ & $\mathrm{C}_{13} \mathrm{H}_{19} \mathrm{~N}$ & 121 & 189 & $\begin{array}{c}82.48 \\
(82.53)\end{array}$ & $\begin{array}{c}10.12 \\
(10.05)\end{array}$ & $\begin{array}{c}7.40 \\
(7.40)\end{array}$ \\
\hline $7 e$ & $\begin{array}{c}3,4- \\
\text { Dichloro }\end{array}$ & $\mathrm{C}_{9} \mathrm{H}_{11} \mathrm{C}_{12} \mathrm{~N}$ & 144 & 202 & $\begin{array}{c}53.49 \\
(53.17)\end{array}$ & $\begin{array}{c}4.49 \\
(5.00)\end{array}$ & $\begin{array}{c}6.93 \\
(6.36)\end{array}$ \\
\hline
\end{tabular}


Table 2. Antibacterial and antifungal data of compounds 7a-e

\begin{tabular}{|c|c|c|c|c|c|c|c|}
\hline \multirow{2}{*}{ Comp } & \multirow[t]{2}{*}{$\mathrm{R}$} & \multicolumn{4}{|c|}{ Antibacterial $^{\mathrm{a}}$} & \multicolumn{2}{|c|}{ Antifungal $^{\mathrm{a}}$} \\
\hline & & S. $a$ & P. $a$ & E.c & S.t & A.n & C. $a$ \\
\hline $7 \mathbf{a}$ & $4-\mathrm{Br}$ & 14 & 14 & 12 & 13 & 10 & 12 \\
\hline $7 b$ & $4-\mathrm{O}-\mathrm{CF}_{3}$ & 09 & 08 & 07 & 10 & 07 & 08 \\
\hline $7 c$ & $4-\mathrm{O}-\mathrm{C}_{6} \mathrm{H}_{5}$ & 08 & 09 & 08 & 09 & 08 & 09 \\
\hline 7d & $4-\mathrm{C}\left(\mathrm{CH}_{3}\right)_{3}$ & 13 & 12 & 14 & 11 & 13 & 14 \\
\hline $7 e$ & 3, 4-Dichloro & 12 & 11 & 13 & 14 & 14 & 14 \\
\hline Penicillin & ------- & 23 & 22 & 23 & 21 & -- & -- \\
\hline Griseofulvin & -------- & --- & --- & --- & --- & 21 & 22 \\
\hline
\end{tabular}

a Zone of inhibition is measured in mm. S.a = Staphylococcus aureus, E.c = Esherichia coli, P.a = Pseudomonas aureus, S.t = Salmonella typhi, A. $n=$ Aspergillus niger, $C . a=$ Candida albicans

\section{Conclusion}

In the present study, a highly efficient and simple procedure for synthesis of substituted azetidine was developed. The adopted method gave good yields. When all the results obtained from antimicrobial and antifungal tests together are considered, it can be said with confidence that the entire series of compounds tested are active towards bacteria and fungi.

\section{Acknowledgement}

The authors are thankful to UGC "Research fellowships in science for meritorious students (RFSMS)" for providing financial support. The authors also thankful to Indian institute of science, Bangalore for providing the spectral and analytical data of the compounds and the Head, Department of Bio technology, Sri Krishnadevaraya University, Anantapur for antimicrobial activity.

\section{References}

1. Padmavathi V, Ramana Reddy T V, Reddy K A, Balaiah A and Padmaja A, Proc Indian Council Chem., 2001, 20, 104.

2. Testa E, Wittigens A, Maffii G and Bianchi G, Research Progress in Organic, Biological and Medicinal Chemistry, Gallo U and Santamaria L, Ed., North-Holland Publishing Co, Amsterdam, 1964, 1, 477.

3. Okutani T, Kaneko T and Masuda K, Chem Pharm Bull., 1974, 22(7), 1490-1497.

4. Kobayashi J, Cheng J, Ishibashi V, Walchli M P, Yamamura S and Ohizumi V, $J$ Chem Soc Perkin Trans., 1991, 1, 1135-1137.

5. Frigola J, Torrens A, Castrillo J.A, Mas J, Vano D, Berrocal J M, Calvet C, Salgado L, Redondo J, GarciaGranda S, Valent E and Quintana J R, Med Chem., 1994, 37, 4195.

6. Cromwell N H and Phillips B, Chem Rev., 1979, 79, 331.

7. Moore J A and Ayers R S, In Small Ring Heterocycles, Hassner A, Ed., Wiley, New York, 1983, 2, 1.

8. Davies D E and Storr R C, In Comprehensive Heterocyclic Chemistry, Lwowski W, Ed., Pergamon, Oxford, 1984, 7, 237.

9. Evans G B, Furneaux R H, Greatrex B, Murkin A S, Schramm V L and Tyler P C, J Med Chem., 2008, 51(5), 948-956.

10. Honcharenko D, Barman J, Varghese O P and Chattopadhyaya J, Biochem., 2007, 46(19), 5635-5646. 
11. Slade J, Bajwa J, Liu H, Parker D, Vivelo J, Chen G P, Calienni J, Villhauer E, Prasad K, Repic O and Blacklock T J, Org Process Res Dev., 2007, 11, 825-835.

12. Zoidis G, Fytas C, Papanastasiou I, Foscolos G B, Fytas G, Padalko E, De Clercq Neyts L E, Naesens J and Kolocouris N, Bio Org Med Chem., 2006, 14, 3341.

13. Nishiyama S, Kikuchi Y, Kurata H, Yamamura S, Izawa T, Nagahata T, Ikeda R and Kato K, Bio Org Med Chem Lett., 1995, 5, 2273.

14. Ungureanu I, Klotz P, Schoenfelder A and Mann A, Chem Commun., 2001, 958-959.

15. Ungureanu I, Klotz P, Schoenfelder A and Mann A, Tetrahedron Lett., 2001, 42, 6087.

16. Prasad B A B, Bisai A and Singh V K, Org Lett., 2004, 6, 4829.

17. Yadav V K and Sriramurthy V, J Am Chem Soc., 2005, 127, 16366-16367.

18. Barluenga J, Fernandez-Mari F, Viado A L, Aguilar E and Olano B, J Org Chem., 1996, 61(16), 5659-5662.

19. Varlamov A V, Sidorenko N V, Zubkov F I and Chernyshev A I, Chem Heterocycl Compd., 2004, 40, 1097.

20. Roos G H P and Donovan A R, Tetrahedron Asymmetry, 1999, 10(5), 991-1000.

21. Aelterman W and De Kimpe N, J Org Chem., 1998, 63, 6.

22. Barluenga J, Tomas M, Ballesteros A and Kong J S, Tetrahedron, 1996, 52, 3095-3106. 